\title{
EVALUASI KECEPATAN TRANSPOR LOGAM DALAM AIR SUNGAI DI DAERAH MURIA
}

\author{
Muzakky \\ Pusat Teknologi Akselerator Dan Proses Bahan, BATAN-Yogyakarta
}

\begin{abstract}
ABSTRAK
EVALUASI KECEPATAN TRANSPOR LOGAM DALAM AIR SUNGAI DI DAERAH MURIA. Telah dilakukan evaluasi kecepatan transpor logam Al, $\mathrm{Mn}, \mathrm{Cd}, \mathrm{As}, \mathrm{Cd}$ dan $\mathrm{Cr}$ di perairan sungai daerah Muria. Kecepatan transpor logam dihitung berdasarkan hasil perkalian antara debit air sungai dengan konsentrasi logam di dalam badan air. Tujuan dari penelitian ini (1) mendapatkan data rona awal lingkungan sungai, (2) memprediksi kualitas air sungai berdasarkan kecepatan transpor logam dan peranan $\mathrm{pH}$ air terhadap perpindahan logam ke dalam sedimen. Pengambilan sampel dipilih pada radius 2 - $5 \mathrm{~km}$ dari calon dibangunnya Pembangkit Listrik Tenaga Nuklir (PLTN) dan dilakukan pada musim penghujan. Berdasarkan indeks kecepatan transpor > $100 \mathrm{mg} / \mathrm{dt}$, hasil evalusi menunjukkan bahwa kecepatan transpor logam sungai Wareng, Balong, Dombang, Kancilan dan Suru telah tercemar oleh logam Mn dan Hg. Sedangkan logam Cd telah mencemari Sungai Balong, Kancilan, dan Suru, logam As mencemari air sungai Kancilan. Kecepatan transpor logam Mn terbesar pada sungai Kancilan 1392,5 mg/dt. Kecepatan transpor logam Cd dan Cr terbesar pada sungai Balong masing-masing sebesar 347,2 mg/dt dan 52,2 mg/dt. Sedangkan kecepatan transpor logam As dan $\mathrm{Hg}$ terbesar didapat pada sungai Kancilan dengan masingmasing 113,8 mg/dt dan 1334,9 mg/dt. Berdasarkan pengamatan pH air, fenomena logam Al, $\mathrm{Mn}, \mathrm{Cd}, \mathrm{As} \mathrm{Cr}$ dan $\mathrm{Hg}$ dalam air sungai di daerah Muria akan cenderung berpindah ke dalam sedimen pada $\mathrm{pH}$ tinggi, sebaliknya pada $\mathrm{pH}$ yang rendah logam-logam akan tetap tinggal dan larut di dalam air.
\end{abstract}

\begin{abstract}
EVALUATION OF TRANSPOR VELOCITY OF METALS IN RIVERS WATER MURIA AREA. The Evaluation of Al, $\mathrm{Mn}, \mathrm{Cd}$, As, $\mathrm{Cd}$ dan $\mathrm{Cr}$ metals transpor velocity in rivers water Muria area have been done. The metals transpor velocity was calculated from multiplication between charge river water with metals concentration on water body. The final purpose experiment is (1) getting of river background level data, (2) to predicted of rivers water quality base on metals transpor velocity and $\mathrm{pH}$ rivers water role in metals migration to sediment at Wareng, Balong, Dombang, Kancilan and Suru rivers. Sampling was done at wet season and location selected at $2 \mathrm{~km}$ until $5 \mathrm{~km}$ from the side of candidate of nuclear power plant. Base on transpor velocity index $>100 \mathrm{mg} / \mathrm{dt}$ evaluation result show that metals transpor successively the Wareng, Balong, Dombang, Kancilan and Suru river all have polluted by $\mathrm{Mn}$ and $\mathrm{Hg}$ metals. While Cd metal have polluted Balong river, Kancilan river and Suru river, the metal As have polluted Kancilan river. Velocity transpor of $\mathrm{Mn}$ metal was faund in Kancilan river was 1392,5 mg/dt, while $\mathrm{Cd}$ and $\mathrm{Cr}$ metals Balong river was $347,2 \mathrm{mg} / \mathrm{dt}$ and $51,2 \mathrm{mg} / \mathrm{dt}$ respectively. While the highest velocity transpor of $\mathrm{As}$ and $\mathrm{Hg}$ metal was found in Kancilan river were 113,8 mg/dt and 1334,9 mg/dt respectively. By obseving of $\mathrm{pH}$ water, the phenomenon $\mathrm{Al}, \mathrm{Mn}$, $\mathrm{Cd}, \mathrm{As} \mathrm{Cr}$ dan $\mathrm{Hg}$ metals in water river of Muria area will tend to moved into the sediment at height $\mathrm{pH}$, on the contrary that the lower $\mathrm{pH}$ the metals will remain and dissolve under water.
\end{abstract}

\section{PENDAHULUAN}

Kegiatan Analisis Mengenai Dampak Lingkungan (AMDAL) di lingkungan Semenanjung Muria merupakan persyaratan penting untuk pembangunan PLTN. Salah satu aktivitas AMDAL yang perlu dilakukan adalah untuk memperoleh data sebaran logam berat terhadap sungai-sungai di sekitar perairan Muria. Walaupun pembangunan PLTN tersebut belum dimulai, tetapi data-data AMDAL setelah lima tahun harus diperbaharui sebagai data "background level" 5 tahunan. Kegiatan rutin ini penting untuk mengevaluasi pencemaran khususnya pencemaran akibat logam berat di Daerah Aliran Sungai (DAS) sekitar Muria. Akibat dari kegiatan AMDAL ini diharapkan gejolak peningkatan atau penurunan logam berat di sekitar Daerah Aliran Sungai (DAS) Muria dapat lebih awal diketahui, sehingga oleh pengambil keputusan PEMDA setempat dapat mencegah atau melokalisir. 
Salah satu kegiatan AMDAL adalah pemantauan yang berguna untuk menentukan konsentrasi kontaminan awal atau rona awal dari dari polutan berbahaya di suatu wilayah tertentu ("background area")(1). Menurut Ziwart dan Trivedi ${ }^{(2)}$, dampak dari kegiatan pemantauan diharapkan dapat melakukan identifikasi ancaman-ancaman yang potensial terhadap kesehatan manusia dan ekosistem alam (ekotoksikologi). Data yang didapat selanjutnya dilakukan evaluasi untuk pemenuhan terhadap beberapa standar pemerintah (PP No 7 1999) ataupun beberapa standar internasional seperti WHO, IAEA, ISD dll. Keluaran kegiatan pemantauan dapat dipakai oleh pengambil keputusan (Pemerintah), untuk diinformasikan kepada masyarakat tentang kualitas lingkungan sungai selajutnya dapat dikembangkan untuk membangkitkan kepedulian masyarakat akan isu-isu lingkungan.

Kegiatan pemantauan dipilih daerah atau area dengan radius $2 \mathrm{~km}$ hingga $5 \mathrm{~km}$ ke darat dari calon tempat dibangunnya PLTN pertama di Indonesia yaitu Ujung Lemahabang. Daerah dengan luasan radius $2 \mathrm{~km}$ hingga 5 $\mathrm{km}$ tersebut, diperkirakan sumber utama penyebab pencemaran selain PLTN sendiri adalah sungai-sungai yang melewati di daerah tersebut. Sungai-sungai yang terdapat pada $2 \mathrm{~km}$ hingga $5 \mathrm{~km}$ seperti Sungai Kancilan, Sungai Balong, Sungai Suru, Sungai Dombang dan Sungai Wareng. Sungai-sungai tersebut diperkirakan membawa polutan ion logam yang berasal dari pelapukan batuan dan mineral, limbah pertanian (pestisida dan pupuk), industri kayu dan limbah domestik yang dibawa dari daerah yang lebih luas radiusnya. Pada daerah radius $2 \mathrm{~km}$ hingga $5 \mathrm{~km}$ di mana muara kelima sungai-sungai tersebut berada, diperkirakan akan terakumulasi pencemar ion logam dari tahun ke tahun akan terus bertambah. Jadi dengan mengambil sampel dari ke lima sungai tersebut untuk ditentukan rona awalnya diharapkan telah memenuhi syarat pemantauan sesuai dengan persyaratan oleh Canter, $19966^{(3)}$.

Menurut Goegoen dan Domini(4), konsentrasi logam berat yang terkandung pada air sungai dan sedimen dapat digunakan sebagai indikator pencemaran sungai. Dengan demikian penentuan konsentrasi ion logam di dalam air sungai dan sedimen merupakan prosedur kendali kegiatan pemantauan. Pada penelitian ini akan dilakukan pengembangan pemantauan lingkungan yang berdasarkan kecepatan transpor logam yang berada di dalam arus air sungai. Kecepatan transpor dipilih karena sesuai dengan data karakteristik fisik nyata yang terdapat pada lingkungan sungai seperti ke dalam, lebar dan kecepatan alir sungai. Perpaduan data kecepatan transpor dan $\mathrm{pH}$ di dalam arus air sungai sangat menentukan perpindahan logam dari badan air ke dalam sedimen. Tujuan penelitian ini adalah untuk memprediksi kualitas dan perananan $\mathrm{pH}$ air sungai berdasarkan kecepatan transpor.

Berdasarkan kondisi sosial dan ekonomi kependudukan daerah di sekitar radius $2 \mathrm{~km}$ hingga $20 \mathrm{~km}$ dari tempat calon lokasi PLTN Muria, pada penelitian atau kegiatan pemantauan ini dipilih polutan logam $\mathrm{Al}, \mathrm{Mn}, \mathrm{Cd}$, As, $\mathrm{Cd}$ dan $\mathrm{Cr}$ dipilih sebagai prosedur kendali . Pemilihan ion-ion logam tersebut karena banyak terdapat pada sisa-sisa kegiatan pertanian dan perkebunan (pestisida dan pupuk), pelapukan batuan / mineral dan sisa buangan bahan pengawet dan industri kayu ${ }^{(5,6)}$. Selanjutnya sebagai evaluasi kendali digunakan PP. No. 82 tahun 2001 tentang pengelolaan kualitas air dan pengendalian pencemaran air tentang baku mutu air yang berdasarkan klasifikasi air sungai.

\section{Teori}

Kecepatan transpor logam di dalam arus air sungai (mg/dt) yang mengalir secara kontinu, merupakan hasil perkalian dari debit air sungai dengan konsentrasi logam yang terdapat di dalam badan air yang dinyatakan dengan ${ }^{(7)}$,

$$
\mathrm{Kt}=\mathrm{D} \times[\mathrm{L}]
$$

Kt merupakan kecepatan transpor (mg/dt), D debit (l/dt) dan [L] konsentrasi logam dalam air (mg/l). Menurut Ziwart ${ }^{(2)}$, bila kecepatan transpor logam yang terdapat di dalam arus sungai lebih besar (>) dari $100 \mathrm{mg} / \mathrm{dt}$, sungai tersebut telah tercemar atau air sungai telah kelebihan dalam mengakumulasi logam di dalam badan air sesuai dengan peruntukannya. 


\section{TATA KERJA}

\section{Peralatan yang digunakan}

Jerigen kapasitas $5 \mathrm{I}$, gayung, plastik klip, sarung tangan, ember, plastik klip $2 \mathrm{~kg}$, alat tulis, kertas saring, cawan pemanas kapasitas $1000 \mathrm{ml}$, gelas ukur, mikropipet, kompor listrik 600 watt, timbangan Analitik OhausGT 410, ayakan Karl Kolb 100 mesh, vial polietilen, alat penumbuk stainless steel dan alat-gelas lain. Seperangkat alat $\mathrm{pH}$ meter jinjing, seperangkat alat currentmeter tipe $\mathrm{TH}-02$ buatan Totonas (pengukur kecepatan alir sungai), reaktor Kartini beserta fasilitas iradiasi Lazy Susan dengan fluks rata-rata $5,1 \times 10^{10} \mathrm{~cm}^{-}$ ${ }^{2} \operatorname{det}^{-1}$ dan daya $100 \mathrm{Kw}$, seperangkat alat spektrometer gamma, dengan detektor Ge(Li) Ortec, MCA Spectrum Master ORTEC 92X dengan software Maestro II, dan perangkat lunak Visual MINTEQ ver 2.50 buatan Land and Water Resources Engineering, Stockholm, Sweden.

\section{Bahan yang digunakan}

Cuplikan air sungai dan sedimen dari pengambilan di semenanjung Muria pada musim penghujan tanggal 22 April 2007 sampai 25 April 2007, aquabides, $\mathrm{HNO}_{6} 65 \%, \mathrm{HNO}_{3} 65 \%$ : Aquabides 1:3, larutan standar $\mathrm{Cd}, \mathrm{Cr}$, As, Al, dan Mn nitrat buatan Merck masing-masing $1000 \mathrm{mg} / \mathrm{l}$, powder yang mengandung $\mathrm{Mg} \mathrm{1,2 \% ,} \mathrm{Al} \mathrm{6,1 \% ,}$ Mn $544 \mathrm{mg} / \mathrm{l}, \mathrm{V} 946 \mathrm{mg} / \mathrm{l}$, Ti 0,457\%, Hg 1,47 mg/l, serbuk selulosa, dan sumber standar multigamma (Eu-152).

\section{Cara kerja}

\section{Lokasi Pengambilan Sampel}

Sampel yang diambil berupa air dan sedimen dengan radius $2 \mathrm{~km}$ hingga $5 \mathrm{~km}$ ke darat dari calon tempat dibangunnya PLTN di semenanjung Muria. Lokasi pengambilan di antaranya, yaitu, Sungai Kancilan, Sungai Balong, Sungai Suru, Sungai Dombang, dan Sungai Wareng. Parameter insitu di lokasi adalah suhu, letak bujur timur dan lintang selatan, debit serta kecepatan arus air. Lokasi dan letak astronomis pengambilan cuplikan seperti dapat dilihat pada tabel 1 .

Tabel 1. Lokasi dan letak astronomis pengambilan cuplikan

\begin{tabular}{|c|l|c|c|}
\hline No. & \multicolumn{1}{|c|}{ Lokasi } & Bujur Timur & Lintang Selatan \\
\hline \hline 1 & Sungai Kancilan & $110^{\circ}, 46^{\prime}, 40,3^{\prime \prime}$ & $06^{\circ}, 30^{\prime}, 04,5^{\prime \prime}$ \\
2 & Sungai Balong & $110^{\circ}, 47^{\prime}, 47,5^{\prime \prime}$ & $06^{\circ}, 28^{\prime}, 04,8^{\prime \prime}$ \\
3 & Sungai Suru & $110^{\circ}, 48^{\prime}, 48,5^{\prime \prime}$ & $06^{\circ}, 26^{\prime}, 43,5^{\prime \prime}$ \\
4 & Sungai Dombang & $110^{\circ}, 49^{\prime}, 43,1^{\prime \prime}$ & $06^{\prime}, 28^{\prime}, 57,8^{\prime \prime}$ \\
5 & Sungai Wareng & $110^{\circ}, 50^{\prime}, 14,7^{\prime \prime}$ & $06^{\circ}, 27^{\prime}, 48,6^{\prime \prime}$ \\
\hline
\end{tabular}

\section{Preparasi sampel air}

Preparasi sampel air dilakukan pada masing-masing lokasi sebelum siap dikenakan iradiasi. Hal ini dilakukan untuk mencegah sampel terkontaminasi dengan bahan atau peralatan lain. Sampel air dalam jerigen diambil 1 liter untuk disaring kotorannya dengan kertas saring sehingga kotoran yang terdapat di dalamnya terbuang. Air sungai hasil penyaringan sebanyak 1 I tersebut kemudian dipekatkan 50 kali dengan alat pendingin kering, menjadi $20 \mathrm{~mL}$ dan dari sampel tersebut diambil sebanyak $1 \mathrm{ml}$ diisikan dalam vial dan ditutup, selanjutnya masing-masing vial dimasukkan dalam kelongsong dan siap untuk dilakukan iradiasi.

\section{Persiapan Iradiasi}

Sampel air yang telah dimasukkan dalam vial, dibungkus dengan plastik klip dan dimasukkan dalam kelongsong dan ditutup rapat. Pada penelitian ini tiap-tiap kelongsong yang dipersiapkan terdiri dari sampel sedimen, air, vial kosong dan sampel standar dalam satu kelongsong yang diatur sedemikian rupa sehingga diperkirakan iradiasi dalam teras reaktor mempunyai fluks neutron yang sama. Kelongsong yang telah 
dipersiapkan dimasukkan ke dalam fasilitas iradiasi Lazy Susan selama 12 jam. Setelah diiradiasi kelongsong dikeluarkan dari reaktor untuk didinginkan selama \pm 4 hari dan siap untuk dicacah dengan spektrometer gamma.

\section{HASIL DAN PEMBAHASAN}

Berdasarkan pengambilan cuplikan pada tanggal 22 April 2007 sampai 25 April 2007 karakteristik sungaisungai di semenanjung Muria pada musim penghujan dapat ditampilkan pada tabel 2.

Tabel 2. Karakteristik sungai Sungai Kancilan, Sungai Balong, Sungai Suru, Sungai Dombang, dan Sungai Wareng

\begin{tabular}{|c|l|c|c|c|c|c|c|}
\hline No & Sungai & Suhu $\left({ }^{\circ} \mathrm{C}\right)$ & $\mathrm{pH}$ & Lebar, $(\mathrm{m})$ & Kedalaman, $(\mathrm{m})$ & Kecepatan, Arus $(\mathrm{m} / \mathrm{det})$ & Debit $\left(\mathrm{m}^{3} / \mathrm{det}\right)$ \\
\hline \hline 1 & Kancilan & 32,3 & 6,8 & 11 & 1 & 0,04 & 0,44 \\
\hline 2 & Balong & 30,5 & 6,2 & 16 & 1 & 0,9 & 14,4 \\
\hline 3 & Suru & 30,5 & 6,5 & 9 & 1 & 0,4 & 3,6 \\
\hline 4 & Dombang & 30,5 & 6,9 & 16 & 1 & 0,9 & 14,4 \\
\hline 5 & Wareng & 29,1 & 6,0 & 4,117 & 1 & 1,167 & 4,395 \\
\hline
\end{tabular}

Berdasarkan Tabel 2, tampak bahwa kedalaman dari ke lima sungai di atas mempunyai karakteristik kedalaman yang relatif sama yaitu $1 \mathrm{~m}$ tetapi lebarnya bervariasi dari $4,11 \mathrm{~m}-16 \mathrm{~m}, \mathrm{pH} 6,2-6,9$, debit air 0,44 $\mathrm{m}^{3} /$ det $-14,4 \mathrm{~m}^{3} /$ det dan suhu 6,2-6,9. Selanjutnya kecepatan tranpor dari sungai Wareng, Balong, Dombang, Kancilan dan Suru berturut-turut dapat ditampilkan pada gambar 1.

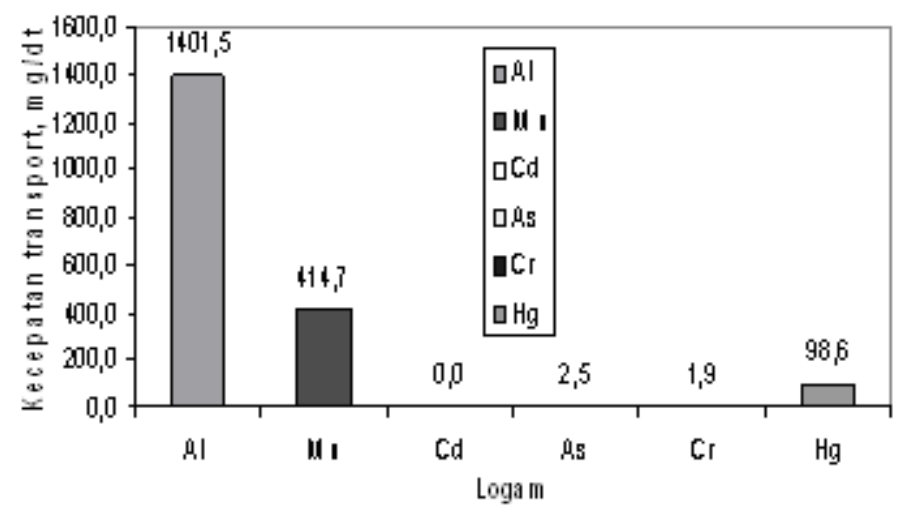

Gambar 1. Kecepatan transpor logam di dalam arus air sungai Wareng

Pada Gambar 1, terlihat bahwa kecepatan transpor logam di dalam arus air sungai Wareng didominasi oleh logam Al, Mn dan Hg dengan harga masing-masing 1401,5 mg/dt, 414,7 mg/dt dan 98,6 mg/dt. Bila dilihat dari kecepatan logam $\mathrm{Mn}$ dan $\mathrm{Hg}$ yang cukup tinggi, berarti pada aliran air sungai Wareng tersebut telah tercemar oleh logam tersebut (>100 mg/l). Pencemaran tersebut kemungkinan besar disebabkan oleh masuknya limbah pertanian dari pupuk atau pestisida, karena di sekitas Daerah Aliran Sungai (DAS) Wareng terdapat perkebunan karet dan coklat. Pada Gambar 1, tersebut tampak juga bahwa kecepatan transpor air sungai tidak mengandung logam $\mathrm{Cd}$, berarti daerah ini tidak tercemar oleh limbah domestik atau konsentrasinya sangat kecil sehingga tidak terdeteksi dengan alat Aktivasi Pengaktifan Neutron (APN). 


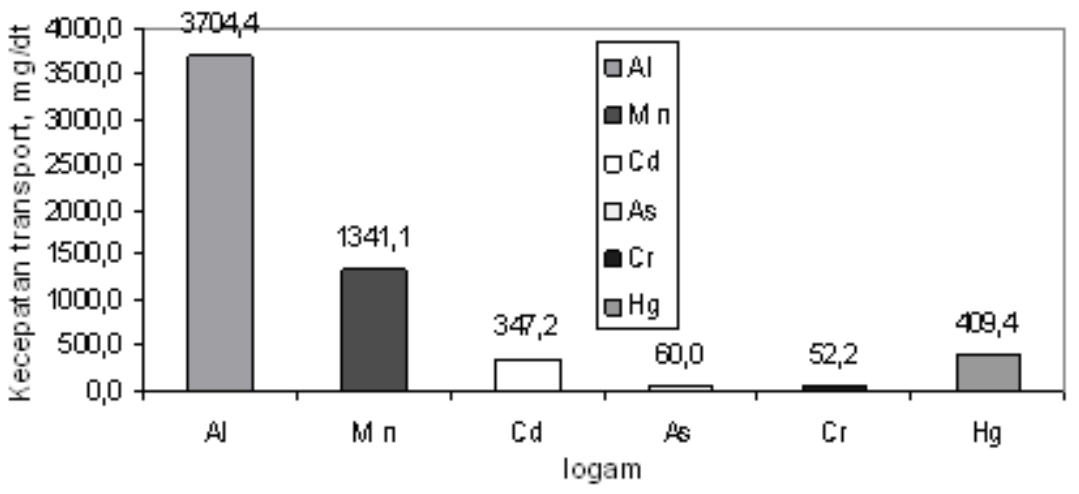

Gambar 2. Kecepatan transpor logam di dalam arus air sungai Balong

Kecepatan transpor arus air sungai Balong seperti yang terlihat pada Gambar 2, didominasi oleh logam Al, $\mathrm{Mn}, \mathrm{Cd}$ dan $\mathrm{Hg}$, hal ini berarti DAS sungai Balong sudah tercemar oleh logam $\mathrm{Mn}, \mathrm{Cd}$ dan $\mathrm{Hg}$ (>100 mg/dt). Pencemaran logam $\mathrm{Mn}$ dan $\mathrm{Hg}$ tersebut kemungkinan besar disebabkan oleh masuknya limbah pertanian dari pupuk atau pestisida, karena di sekitar Daerah Aliran Sungai (DAS) Balong terdapat perkebunan karet dan coklat. Selanjutnya dengan terdeteksinya logam Cd berarti air sungai Balong telah tercemar oleh limbah domestik atau buangan limbah industri kayu. Prediksi ini dapat dilihat dengan naiknya kecepatan transpor logam As dan $\mathrm{Cr}$ dari sungai Balong yang lebih tinggi dari pada sungai Wareng yang letak geografinya berjauhan dan lebih ramai dari aktivitas manusia.

Berdasarkan data kecepatan transpor logam pada arus sungai Dombang pada Gambar 3, ternyata masih didominasi oleh logam $\mathrm{Al}, \mathrm{Mn}$ dan $\mathrm{Hg}$, berarti air sungai tersebut telah tercemar logam $\mathrm{Mn}$ dan $\mathrm{Hg}$ (kecepatan transpor $>100 \mathrm{mg} / \mathrm{dt}$ ). Pada arus air sungai Dombang ternyata juga terdeteksi adanya logam $\mathrm{Cd}$, As dan $\mathrm{Cr}$ walaupun tidak sebesar konsentrasi di sungai Balong . Dari data tersebut berarti air sungai Dombang telah tercemar oleh limbah domestik atau buangan limbah industri kayu. Berdasarkan karakteristik antara sungai Balong dan Dombang yang sama (Tabel 1), ternyata harga pH dari keduanya berbeda yaitu 6,2 untuk sungai Balong dan sungai Dombang sebesar 6,9.

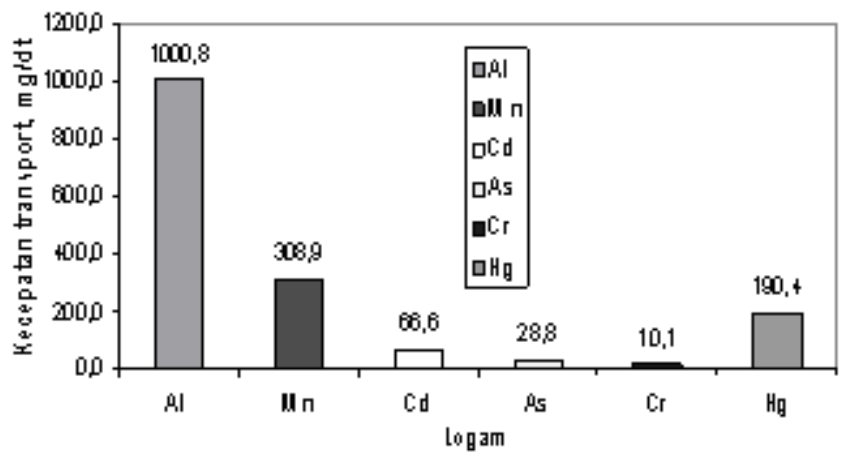

Gambar 3. Kecepatan transpor logam di dalam arus air sungai Dombang

Pada penelitian sebelumnya ${ }^{(7)}$, spesies $\mathrm{Al}^{3+}$ di dalam air pada kondisi $\mathrm{pH}$ 6,2 akan didominasi oleh spesies $\mathrm{Al}_{3}(\mathrm{OH})_{4}{ }^{+5}$ yang bersifat kation sedangkan pada suasana $\mathrm{pH} 6,9$ didominasi oleh spesies $\mathrm{Al}(\mathrm{OH})^{4-}$ yang bersifat anion. Sedangkan data kecepatan transpor logam Al di sungai Dombang lebih kecil daripada di sungai Balong. Hal ini merupakan jawaban mengapa, kecepatan transpor logam Al, Mn dan Cd di sungai Dombang lebih kecil dari sungai Balong. Pada kondisi $\mathrm{pH}$ 6,9 tersebut spesies $\mathrm{Al}(\mathrm{OH})^{4}$ yang bersifat anion akan lebih mengikat logam $\mathrm{Mn}$ dan $\mathrm{Cd}$ yang bermuatan positif, akibatnya kedua logam tersebut diperkirakan akan lebih cenderung mengendap ke dalam sedimen dan akibatnya konsentrasi logam Mn dan Cd lebih kecil. 


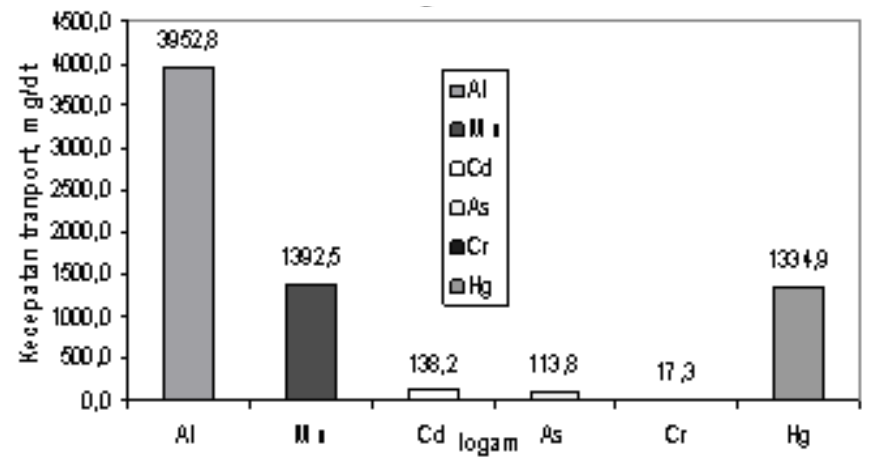

Gambar 4. Kecepatan transpor logam di dalam arus air sungai Kancilan

Berdasarkan data kecepatan transpor logam di dalam arus sungai Kancilan pada Gambar 4, ternyata telah didominasi oleh logam $\mathrm{Al}, \mathrm{Mn}, \mathrm{Cd}$, As dan $\mathrm{Hg}$, berarti air sungai tersebut telah tercemar logam $\mathrm{Mn}, \mathrm{Cd}, \mathrm{As}$ dan $\mathrm{Hg}$ (kecepatan transpor $>100 \mathrm{mg} / \mathrm{dt}$ ). Berdasarkan data pada Gambar 4 di atas, sungai Kancilan merupakan sungai yang paling tercemar logam $\mathrm{Mn}, \mathrm{Cd}$, As dan $\mathrm{Hg}$ dibandingkan dengan sungai-sungai Wareng, Balong dan Dombang. Pencemaran ini kemungkinan disebabkan oleh debit sungai Kancilan yang paling rendah dibandingkan sungai Wareng, Balong dan Dombang. Pada keadaan debit sebesar 0,44 $\mathrm{m}^{3} / \mathrm{dt}$ (Tabel 1), kontaminasi logam yang masuk ke dalam sungai Kancilan diperkirakan akan lebih cepat terakumulasi dan tidak menyebar ke daerah yang lebih luas. Akibatnya konsentrasi logam $\mathrm{Al}, \mathrm{Mn}, \mathrm{Cd}, \mathrm{As}$ dan $\mathrm{Hg}$ di dalam arus air sungai Kancilan tersebut lebih tinggi dibanding sungai Wareng, Balong dan Dombang.

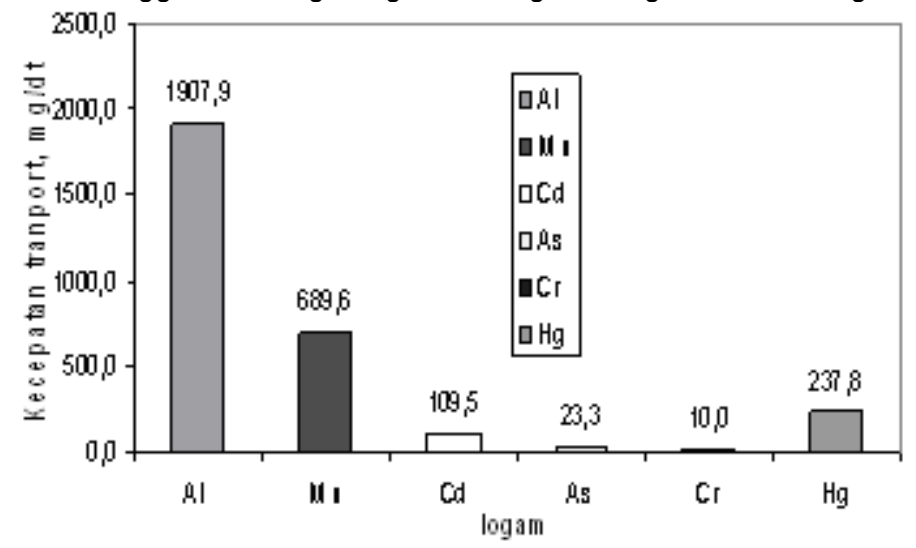

Gambar 5. Kecepatan transpor logam di dalam arus air sungai Suru

Seperti halnya sungai Dombang ternyata data kecepatan transpor di dalam arus sungai Suru pada Gambar 5, ternyata lebih didominasi oleh logam $\mathrm{Al}, \mathrm{Mn}, \mathrm{Cd}$, dan $\mathrm{Hg}$. Hal ini berarti air sungai Suru tersebut telah tercemar logam $\mathrm{Mn}, \mathrm{Cd}$ dan $\mathrm{Hg}$ (kecepatan transpor $>100 \mathrm{mg} / \mathrm{dt}$ ). Dari data tersebut berarti air sungai Suru telah tercemar oleh limpahan limbah domestik atau buangan limbah industri kayu. Berdasarkan pada Anonim ${ }^{(1)}$ pada kondisi $\mathrm{pH}$ yang tinggi, biasanya logam-logam akan cenderung keluar dari badan air sungai dan mengendap kedalam sedimen, sebaliknya pada pH yang rendah logam-logam akan tetap tinggal dan larut di dalam air. Ternyata penomena tersebut tidak bertentangan dengan hasil dari data pengamatan kecepatan transpor dari sungai-sungai Wareng, Balong, Dombang, Kancilan dan Suru seperti terlihat pada Gambar 6 dan 7. 


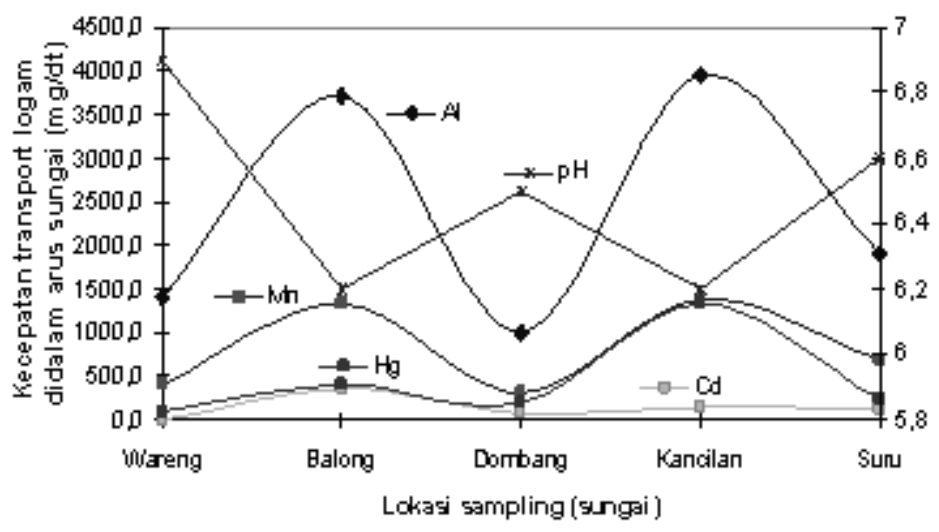

Gambar 6. Perbandingan antara pola sebaran kecepatan transpor logam $\mathrm{Al}, \mathrm{Mn}, \mathrm{Cd}$ dan $\mathrm{Hg}$ di dalam arus air sungai Wareng, Balong, Dombang, Kancilan dan Suru dengan pH air

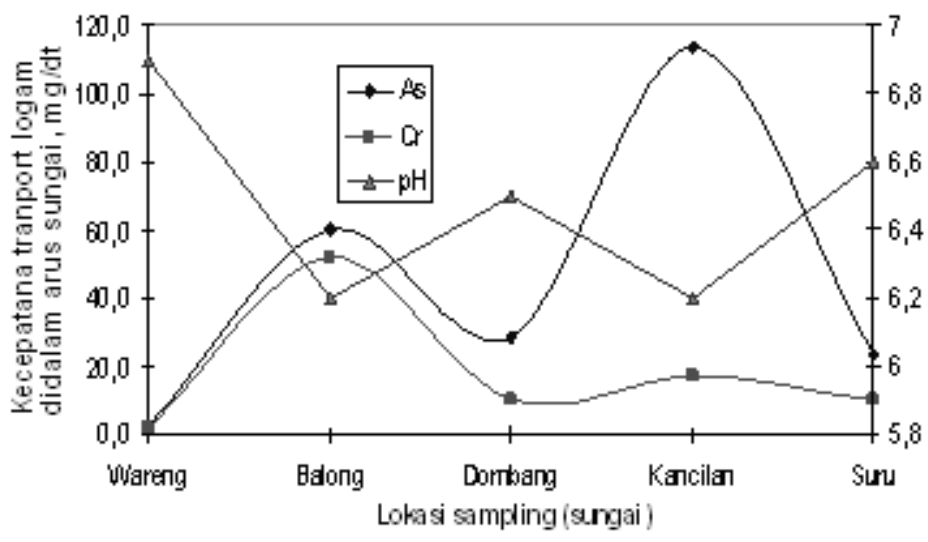

Gambar 7. Perbandingan antara pola sebaran kecepatan transpor logam As dan $\mathrm{Cr}$ di dalam arus air sungai Wareng, Balong, Dombang, Kancilan dan Suru dengan $\mathrm{pH}$ air

Pada Gambar 6, terlihat bahwa pola sebaran konsentrasi logam-logam $\mathrm{Al}, \mathrm{Mn}, \mathrm{Cd}$ dan $\mathrm{Hg}$ yang bermuatan positif dalam larutan air akan berbanding terbalik dengan pola $\mathrm{pH}$ air yang terdapat pada sungai Wareng, Balong, Dombang, Kancilan dan Suru. Dari data pada gambar 6 tersebut diperkirakan, berturut-turut pada sungai Wareng, Dombang, dan Suru logam-logam Al, Mn, Cd dan Hg akan cenderung berpindah kedalam sedimen. Selanjutnya pada sungai Balong dan Kancilan logam-logam Al, $\mathrm{Mn}, \mathrm{Cd}$ dan $\mathrm{Hg}$ tersebut akan tetap tinggal di dalam badan air dan tidak berpindah kedalam sedimen.

Sebaliknya penomena juga terjadi pada Gambar 7, ternyata pola sebaran logam As dan $\mathrm{Cr}$ yang bermuatan negatif dalam larutan akan sama dengan pola $\mathrm{pH}$ air yang terdapat pada sungai Wareng, Balong, Dombang, Kancilan dan Suru di Gambar 6. Dari data pada gambar 7 tersebut diperkirakan, berturut-turut pada sungai Wareng, Dombang, dan Suru logam As dan $\mathrm{Cr}$ akan cenderung berpindah kedalam sedimen. Selanjutnya pada sungai Balong dan Kancilan logam As dan $\mathrm{Cr}$ akan tetap tinggal di dalam badan air.

\section{KESIMPULAN}

Berdasarkan indeks kecepatan transpor $>100 \mathrm{mg} / \mathrm{dt}$, hasil evalusi menunjukkan bahwa kecepatan transpor logam sungai-sungai di perairan sungai Muria, berturut-turut sungai Wareng, Balong, Dombang, Kancilan dan Suru semua telah tercemar oleh logam $\mathrm{Mn}$ dan $\mathrm{Hg}$. Sementara logam $\mathrm{Cd}$ telah mencemari Sungai Balong, Kancilan, dan Suru, dan air sungai Kancilan ternyata telah tercemar oleh logam As. Kecepatan transpor logam $\mathrm{Mn}$ terbesar diperoleh oleh sungai Kancilan 1392,5 mg/dt, kemudian kecepatan transpor untuk logam $\mathrm{Cd}$ dan $\mathrm{Cr}$ terbesar diperoleh sungai Balong masing-masing sebesar 347,2 mg/dt dan 52,2 mg/dt. Sementara untuk kecepatan transpor logam As dan $\mathrm{Hg}$ terbesar akan didapat oleh sungai Kancilan dengan masing-masing 113,8 $\mathrm{mg} / \mathrm{dt}$ dan 1334,9 mg/dt. Berdasarkan pengamatan pH air, fenomena logam $\mathrm{Al}, \mathrm{Mn}, \mathrm{Cd}, \mathrm{As} \mathrm{Cr}$ dan $\mathrm{Hg}$ dalam air 
sungai di daerah Muria akan cenderung berpindah kedalam sedimen pada $\mathrm{pH}$ tinggi, sebaliknya pada $\mathrm{pH}$ yang rendah logam-logam akan tetap tinggal dan larut di dalam air.

\section{DAFTAR PUSTAKA}

1. ANONIM, (2003), Guidance for Environmental Background Analysis., vol.Il.sediment., NFECS user guide UG-2054ENV., Naval Facilities Engineering Command., Washington DC 20374-5065.

2. ZIWART.D., AND TRIVEDI.R.C.,(1994)., Manual on intergrated water quality evaluation., report 802023003. , Biomonitoring Indian River II., RIVM proyect 754192 IN/92/021.

3. CANTER.L.W., (1996)., "Environmental Impact Assessment",, McGraw-Hill, Inc., New York

4. GOEGOEN.C AND DOMINI.J.,(2003)., Partitioning of Trace Metals between Particulate, Colloidal and Trully Dissolved Fractions in Polluted River: The Upper Vistula River (poland)., Applied Geochemistry, vol 18, p.457-470.

5. ROSS.S.M.,(1994)., Toxic Metals in Soil-Plant Systems., John Wiley \& Sons., New York.

6. RADOJEVIC DAN BASHKIN, (1999)., Practical Environmental Analysis., w.w.w.rsc.org., The Royal Society of Chemistry., Paston PrePress Ltd, Suffolk.NR34 9QG.,UK.

7. MUZAKKY., (2005)., Dinamika Perpindahan Logam di Lingkungan Perairan Sepanjang Sungai Code, Yogyakarta. Tesis S2, FMIPA-Kimia UGM

\section{Lampiran : Gambar lokasi calon PLTN Muria}

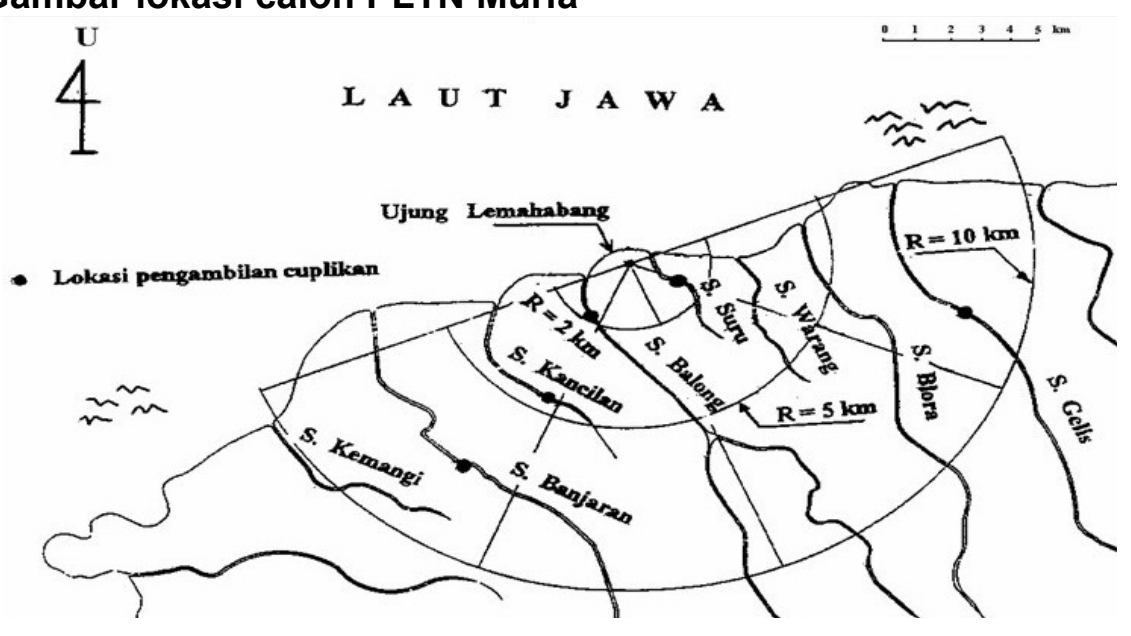

